\title{
Homeless Existence of Floating Artists in Nocturnes
}

\author{
Jueyun Li \\ Shandong University of Art \& Design, Jinan, Shandong, China
}

\begin{abstract}
As demonstrated in most of his earlier novels, Ishiguro tends to present his protagonists as artist or someone who has been infatuated with the functions of art. In Nocturnes, Ishiguro has chosen different settings such as Europe and America for the narratives entangling among different places. Just like what the narrator Janeck confesses, as a foreigner living in Venice he has always been regarded as one of the gypsies.
\end{abstract}

Index Terms - Psychological identification, Post-Enlightenment, Nostalgia

Through the similar theme of elegiac or croony music, readers have been reminded of the narrators' Kafkaesque wanderings across different cities and even countries, which points towards the humanistic dignity and even resignation to the mediocrity of human life. Despite the obvious desperation the narrators have encountered, they still tend to resolve the realistic cause which has destroyed their happiness of life. The predicament their floating life has caused has always been awaiting these lonely musicians and frustrated teachers, which somehow coerces them to quit their usual identities and become others in order to achieve the fulfillment of their dreams. Like Ryder in The Unconsoled, Janeck has been one of the "gypsies" moving around the piazza, and complains the discrimination of "tradition and the past, everything's upside down" (NOCT, 3). As Naipaul argues, the national prejudice of Englishness turns out to be "the product of fantasy, a work of national art; it will outlast England" (Naipaul, 215). That is to say, the dreamlike idealism these characters have pursued for their formulation of identities, such as Tony Gardner, Raymond and even Steve, has transformed them into the Hemingwayesque heroes who struggle against the compromise of secular life for their musical contribution to humankind.

\section{Non-human Identity of Floating Strangers}

Unfortunately, the distance between the aesthetic art and secular reality somehow leads to such narrators' bewildering about their responsibilities and memories of past losses or wounds. As the Godfather performances have indicated, the narrator Janeck can be perceived as the same protagonist of both stories "Crooner" and "Cellists", who embarrassedly discovers how "the bosom pals of today become lost strangers tomorrow, scattered across Europe, playing the Godfather theme or 'Autumn Leaves' in squares and cafes you'll never visit" (NOCT, 190). In other words, Ishiguro carries into this book his consistent "questions of art's obligation and ability to evoke or to penetrate the surface of ordinary people's lives" (Wormald, 235), which repeatedly confirms the mysterious power of their cultural and social identity of human beings.

Along the music journey of these narrators, we encounter musical dreamers, jobbing musicians and even bygone singers who foreground themselves from one Italian piazza to the
Malvern Hills, from a London flat to an expensive Hollywood hotel. Like the Narrator Ryder in The Unconsoled, the musicians like Tilo and even Tony Gardner still believe that "it's good that we perform to all kinds of people" (NOCT, 112), which nevertheless demonstrates their identities of being needed by people who encounter such terrible problems. And seemingly intractable problems. Nevertheless, these narrators have ultimately transformed into the strangers to their own consciousness and psychological identification, which arouses their "moments of self-awareness when each of the many poles of one's 'ambiguous' asserts [...] always involves denial of something which at times at least, we know to be true of ourselves" (Cooper, 119).

As the creation of transcultural forms, hybridity of human identity formulates one debatable notion of the individual status and position, which indicates "a strong sense of dynamic contrariety persists, with both regional and ethic implications" (Lane et al., 143). Because of their "not being Italian, never mind Venetian" (NOCT, 4), such musicians like Janeck have to suffer the plights of not fitting the official bill as a regular band member, in spite of the fact that "We're well liked, we're needed by the other musicians" (NOCT, 4). Indeed, such Italian residents like the gondolier Vittorio prefer more to live in tradition or nostalgia, through which they "want something they recognise, maybe an old Julie Andrews number, or the theme from a famous movie" (NOCT, 4). In a word, music or song possesses a dynamic power that can present people the dreamlike life they have not deserved and even fulfill their self-affirmation in such an artistic and illusory world, despite its permeating a variety of different imperfections and pains. That is to say, the narrators of his novels, such as An Artist of the Floating World and The Unconsoled, seem to raise the question of the role the artistic or aesthetic values have performed in exploring the tropes of "the aspiration to create through the power of art compensatory 'imaginary homelands' (in Rushdie's phrase) for their exiled and deracinated characters" (Wormald, 226).

In pursuit of their fame and fortune, the musicians and even music lovers have to suffer the suffocating and absurd reality of human life, which somehow reminds Janeck of Tony's influence upon his mother during the communist period. Realizing the fact that Tony Gardner's records have transformed his exhausted and even broken-hearted mother so much for "her sake, for the sake of her memory" (NOCT, 6 ), the roving guitarist chooses to encounter and accompany this legendary American crooner to perform his extraordinary serenade before their divorce. That is to say, the affirmation of cultural identity has also reflected in the illusion of music world, which "contains more truth than does everyday reality [...] mystified in its institutions and relationships, which make 
necessity into chance, and alienation into self-realization" (Marcuse, 54).

Despite Janeck's belief in the fascination of music which certainly exceeds the limitations of different nations, such people still believing in art nevertheless arouse the hostility from the extreme nationalists like Vittorio who would rather walk around saying "foreigners like me, we go around ripping off tourists, littering the canals, in general ruining the whole city. Some days, if he's in a bad mood, he'll claim we're muggers - rapists, even" (NOCT, 17). Furthermore, the juxtaposition of different national cultures somehow represents the confliction and even celebration of social hybridity, which results from the reconstruction of a post-modernist society. Suffering the narrators' floating status, they still choose to remain the belief that their artistic creation will certainly contribute to the humanistic idealism of society. Just like what Tony comments upon his encounter with Janeck, "what I intended to say to you, friend, what I meant was that coming from where you do, quite naturally, there are many things you don't understand yet. Just like there'd be many things I wouldn't understand in your country" (NOCT, 16).

Furthermore, the encounter of different cultures leads to no assimilation and compromise, but the prejudice and strangeness, which results in Janeck's anxiety of the following emergence that "when Mr. Gardner started singing, Mrs. Gardner would come to the window with a gun and fire down at us" (NOCT, 17). In fact, the characters like Tony and Janeck have tried to achieve their attempts to wipe off the barriers between sacred beauty of music and the filthy vulgarity of reality, which somehow arouses Janeck's disappointment of noticing Tony "wasn't really listening to our music" (NOCT, $6)$. In order to cover up the failure to communicate with his audience, Tony even bestows high standards of eating pork chops on a Milwaukee audience when appreciating his music, which somehow contributes to their understanding, through the way "the audience becomes someone you know, someone you can perform to. There, that's my secret" (NOCT, 18). Despite their suffering frustrating reality, these people still choose to restore the romantic illusion into their everyday life, which nevertheless confirms the consoling power of music in helping "my mother through those times, it must have helped millions of others" (NOCT, 24). As Rushdie states in The Ground Beneath Her Feet, "Why do we care about singers [...] Song shows us a world that is worthy of our yearning, it shows us ourselves as they might be, if we were worthy of the world" (Rushdie, 19-20).

Faced with the pressure of social reality, people like Tony and Lindy prefer to transform their personal identities they have once been familiar with in order to follow the sound and fury of human life. For the pursuit of his musical career, Tony would rather choose to divorce from his wife than stay together for ever, which means his being "prepared to make a lot of changes, some of them hard ones. You change the way you are. You even change some things you love" (NOCT, 30). Instead of keeping watch her love and matrimony, Lindy also prefers to "get out now, while she has time. Time to find love again, make another marriage" (NOCT, 31), although she still "loves me as much as I still love her" (NOCT, 29). Therefore, the suffering which belief in art has brought about does not disappear with the prevailing of secularism, and becomes even more obvious in the loss of human identities. Just as Anderson argues, the domination of Post-Enlightenment secularism surprisingly becomes "a secular transformation of fatality into continuity, contingency into meaning [...] It is the magic of nationalism to turn chance into destiny" (Anderson, 11).

\section{Self-assertion in Pursuit of Cultural Identity}

The freedom of individual identity relies more on the rational reality, which has been ideologically circumscribed and even represented by the facticity of human life. Because of the fragmentary and superficial Post-Modernism prevailing, these people such as Lindy and Tony have been transformed into a unity of conflicts, which compete to control their cultural identities betokened by "our class origin, our jobs, the circuits of our friendships and desires, our ways of spending our leisure time, our literary predilections, our political affiliations - or lack of them" (Ahmad, 138). Accompanied by the dominating reality and its embodiments, what the art reveals is its groundlessness and fragility, which nevertheless arouses people's doubt about the polytropism of cultural identity reflecting their double-voicedness of human consciousness.

Indeed, all the stories in Nocturnes, except the second one "Come Rain or Come Shine", foreground the itinerant working musicians, and even the narrator Raymond madly clings to such croony music of American Broadway singers in order to escape from "moaning about exactly the same things" (NOCT, 45) of his hopeless situation. Due to their cultural migrancy and rootlessness, these characters like Janeck have been estranged from any immigrated culture they have inherited in order to fulfill their spiritual requirements of "imaginary homeland". As Raymond claims, since his graduation from college, he has "spent years here in Spain, as well as in Italy and Portugal, while Charlie's [...] always flying off - to Texas, Tokyo, New York - to his high-powered meetings" (NOCT, 39). As the figures who straddle different cultures, these people such as Raymond and Tibor turn out to represent a playful portrayal of cultural hybridity existing in our postmodern society, which has been presented by the image of someone who "listens to reggae, watches a western, eats McDonald's food for lunch and local cuisine for dinner, wears Paris perfume in Tokyo and 'retro' clothes in Hong Kong" (Lyotard, 42).

The universalism of culture nevertheless points to the hybridity of identity, which is filled with ambiguity and contradiction undermining the dominant ideology. As one itinerant language teacher, Raymond enjoys his life, in which he feels like "you're apart of a large network extending around the entire globe. You meet people fresh from their spells in Peru or Thailand [...] always you'd be part of this cosy, extended family of itinerant teachers" (NOCT, 40). However, the transition and transformation of his identity which opens up some possibility that can bridge the chasm of different 
cultures becomes "a process of displacement and disjunction that does not totalize experience. Increasingly, 'national' cultures are being produced from the perspective of disenfranchised minorities" (Bhabha, 5-6). Indeed, the cultural alienation of Raymond's floating life makes himself always feel slightly let down, and ultimately leads to his desperately imagining that "being godfather to one of their children would provide an official link, however tenuous, between their lives in England and mine out here" (NOCT, 41).

Nevertheless, the influence Raymond has derived from his identity of cultural hybridity offers him some perspective to "stop and ask yourself who you are" (NOCT, 49), which somehow acknowledges his compromise with the current capitalist ideology. Instead of accepting the fate of being an ordinary bloke, Emily complains about the waste of Raymond's and even Charlie's potential, through which they have been "destined for [...] God knows, president of the fucking world" (NOCT, 50). Compared with the nostalgia of her past university life, Emily even thinks of her friend as "only a husk of the Raymond from those days" (NOCT, 53), and begins to dream about such wonderful figures like David bloody Corey and Roger Van Den Berg as her potential lovers because of their great accomplishments, which somehow results in their marital crisis of "what's so pathetically sad and ironic about all this, the point is, at the bottom of it all. She loves me. She still loves me" (NOCT, 61). With the emergence of increasing minorities, Europeanism and even Anglicism can't be imagined or reassessed without any reference to the otherness existing in Europe which has become "a hybridity creation of those who, like himself, seek to define themselves against or inside it" (Buchanan, 181). Perhaps through the portrayal of such identity-ridden wanderers between Britain, Continental Europe and America, Ishiguro attempts to present readers some pessimistic viewpoint of culture which leads to their wondering "where to settle. What to settle to" (NOCT, $85)$, which contributes to their post-Freudian tension inside human life.

In fact, the cultural identity Raymond represents has never transformed into the idealized 'third space' of carnivalesque hybridity, which can help "sustain me through my lousiest moments in strange and lonely countries" (NOCT, 62). Like Tilo and Sonja who are wandering musicians, Raymond and even Emily have to resort to the croony nostalgia music in order to shake off the sound and fury of secular culture, which nevertheless pushes the farcical comedy of bridge the marital fissure into a bittersweet drama. Similarly, Charlie, like Emily, also tends to establish a model of potential lover whose untarnished idealism of "education in the developing world, and fairer global trade" (NOCT, 73) has reminded himself of "this other me, the one that's been trapped inside" (NOCT, 74). As the pathetic beings, these characters have all suffered despondent things such as a total mess of work, estrangement of friendship and marriage and even lingering around the edge of life, which somehow reflects their cultural status of marginality and placelessness beneath its simple imperial idealism of the so-called Englishness. Due to the confusing displacement of cultural identity, "the private and the public become part of each other, forcing upon us a vision that is as divided as it is disorienting" (Bhabha, 9).

\section{Conclusion}

Because of the predicaments they have encountered, Emily anxiously regards the all-fours posture of his impersonating a dog to cover up the damage of her diary, and even his prepared cooking of one boot to make up the doggy smell as one symptom of despondence and wishful suicide, which betokens their never being contented with human facticity. Most importantly, what has been left over for them to console their own injured souls is this croony nostalgia music through which some "sense of relief and comfort washed over me" (NOCT, 81), and even brings them back to memories of past happiness which ultimately turns out to be a process of cultural "in-between spaces through which the meanings of cultural and political authority are negotiated" (Bhabha, 4). In a sense, Ishiguro has always remained influenced by his double-identified life, which has, for one reason or another, been ready to penetrate into his portrayal of characters in his creation of universal writings.

\section{References}

[1] Ahmad, A. In Theory: Classes, Nations, Literatures, London: Verso, 1992.

[2] Anderson, B. Imagined Communities, London: Verso, 1991.

[3] Bhabha, H. The Location of Culture. London: Routledge, 1994.

[4] Buchanan, B. "Caryl Phillips: Colonialism, Cultural Hybridity and Radical Difference", in Richard J. Lane, Rod Mengham and Philip Tew (ed.) Contemporary British Fiction, Cambridge: Polity Press, 2003.

[5] Cooper, D. E. Existentialism, Oxford: Blackwell, 1990.

[6] Ishiguro, K. Nocturnes: Five Stories of Music and Nightfall, New York: Vintage, 2009.

[7] Lane, R. J., Rod Mengham and Philip Tew, Contemporary British Fiction, Cambridge: Polity Press, 2003.

[8] Lyotard, J. "Answering the Question: What is Postmodernism?", in Thomas Docherty (ed.) Postmodernism: A Reader, London: Harvester, 1993.

[9] Marcuse, H. The Aesthetic Dimension: Toward a Critique of Marxist Aesthetics, London: Macmillan, 1978.

[10] Naipaul, V. S. An Area of Darkness, New York: Vintage Books, 2002.

[11] Rushdie, S. The Ground Beneath Her Feet, London: Jonathan Cape, 1999.

[12] Wormald, M. "Kazuo Ishiguro and the Work of Art: Reading Distances", in Richard J. Lane, Rod Mengham and Philip Tew (ed.) Contemporary British Fiction, Cambridge: Polity Press, 2003. 